\title{
Addressing the Challenges of Sustainable Rural Infrastructure Delivery in Nigeria: Focus on Ondo North Senatorial District
}

Opeyemi Alonge, Tolu Lawal, Oladiran Akindiyo

To Link this Article: http://dx.doi.org/10.6007/IJARBSS/v11-i2/8876

DOI:10.6007/IJARBSS/v11-i2/8876

Received: 20 December 2020, Revised: 22 January 2021, Accepted: 05 February 2021

Published Online: 25 February 2021

In-Text Citation: (Alonge et al., 2021)

To Cite this Article: Alonge, O., Lawal, T., \& Akindiyo, O. (2021). Addressing the Challenges of Sustainable Rural Infrastructure Delivery in Nigeria: Focus on Ondo North Senatorial District. International Journal of Academic Research in Business and Social Sciences, 11(2), 619-631.

\section{Copyright: (c) 2021 The Author(s)}

Published by Human Resource Management Academic Research Society (www.hrmars.com)

This article is published under the Creative Commons Attribution (CC BY 4.0) license. Anyone may reproduce, distribute, translate and create derivative works of this article (for both commercial and non-commercial purposes), subject to full attribution to the original publication and authors. The full terms of this license may be seen at: http://creativecommons.org/licences/by/4.0/legalcode

Vol. 11, No. 2, 2021, Pg. 619 - 631

Full Terms \& Conditions of access and use can be found at http://hrmars.com/index.php/pages/detail/publication-ethics 


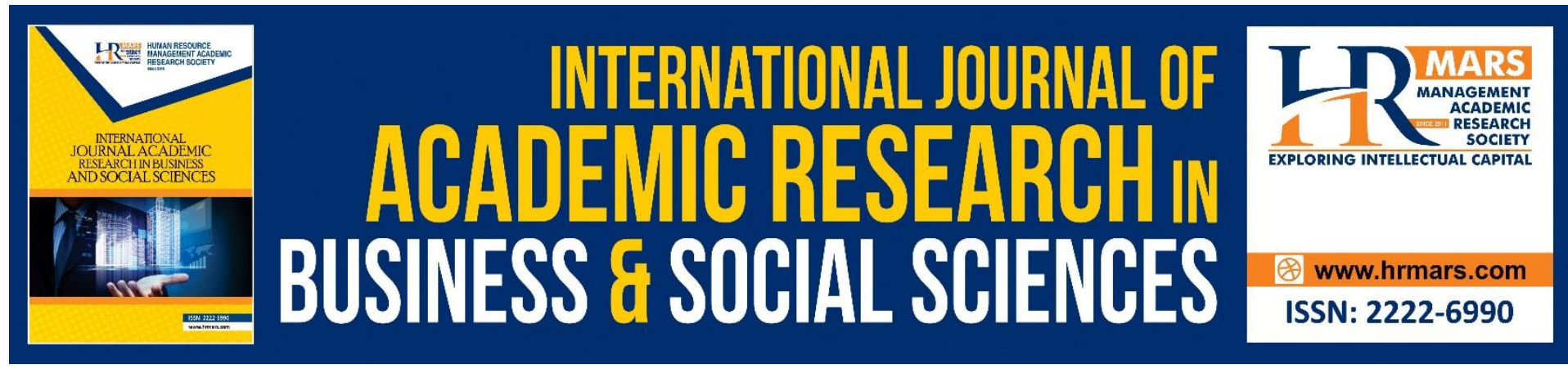

\title{
Addressing the Challenges of Sustainable Rural Infrastructure Delivery in Nigeria: Focus on Ondo North Senatorial District
}

\author{
Opeyemi Alonge, Tolu Lawal, Oladiran Akindiyo \\ Department of public administration, Rufus giwa polytechnic, owo Ondo state, Nigeria \\ Email: opeadewumi@yahoo.com, lawtolous@yahoo.com, akindiyooladiran73@gmail.com
}

\begin{abstract}
Rural communities play a vital role in economic development of nations, particularly, the developing nations, where the source of food and other raw materials needed for production activities remains with rural communities. Given this laudable role, it is therefore expected that rural communities enjoy the presence of government through the provision and delivery of rural infrastructures. However, most rural communities in Nigeria have been deprived of these infrastructures as basic and essential facilities are grossly lacking and where available, are inadequate. As a result, rural communities have continued to experience preventable diseases and avoidable hardship. Based on this, the study examined the challenges of sustainable rural infrastructure delivery in Nigeria with specific focus on rural water, electricity, roads and health services in the northern senatorial district of Ondo state. Both primary and secondary methods were adopted to source the needed data. Interviews were conducted to elicit data from the residents of the communities. The study found that rural communities in Nigeria, particularly in Ondo State were severely challenged by inadequate infrastructure and hence the urgent need to address to infrastructure gaps.
\end{abstract}

Keywords: Community, Infrastructure, Development and Rural

\section{Introduction and the Problem}

Infrastructure is the complex of physical structures or networks within which social and economic activities are carried out. These structures are not ends in themselves, but are means to achieving the broader goals of poverty reduction and economic growth and development. Infrastructure contributes to these goals by providing essential services such as water, light, roads, transport of goods and people, particularly in the rural communities (Gnade, 2013; Lawal and Imoukhuede, 2018).

In Africa, infrastructural development models have entered a period of transition, moving away from centrally-controlled public sector provision to a more demand-driven and decentralized delivery models (Ogbuagu et al; 2014). The Nigerian government through the tiers of government is expected to develop and provide its citizens with basic infrastructure, such as good road network, functional health care delivery system, educational facilities, regular electricity supplies and portable water supplies as access to infrastructure is considered a basic human need, irrespective of where people live, gender or income level 
(Uhunmwuangho and Ekpu, 2012). By implication, the three tiers of government have to plan to ensure that citizens basic needs are provided in compliance with the fundamental objectives and directive principles of state policy as stated and enumerated in chapter II, section 16, 17, 18 and 20 of the 1999 constitution.

Experience from infrastructure development programmes clearly shows that infrastructure in rural communities in Nigeria is severely degraded and this imposes high transaction cost on the rural population, $80 \%$ of rural roads are in poor condition. Similarly, $70 \%$ of rural communities do not have access to piped drinking water and water quality is alarmingly poor (World Bank, 2014).

In the past, there have been extensive studies on infrastructure, but the fact remains that the impact gaps of infrastructural delivery in rural communities are largely under studied as most studies were focused on the provision and availability of these infrastructure rather than its impact on the rural dwellers. As a result of this, the need for more research work on impact gaps on rural communities becomes imperative.

It is also instructive at this juncture to know that the various attempts at bridging infrastructure gaps in rural communities by successive governments had not yielded any positive effect. Consequently, rural communities have continued to experience rural underdevelopment and infrastructural deficit due to failure of government infrastructure programmes. Arising from the foregoing, practitioners, users, researchers and development agencies are now posing the question, how can rural communities not only provide physical infrastructure, but also ensure that infrastructures are continuously provided on sustainable basis at appropriate levels of quality and affordability? Based on these, the paper is set to critically examine the challenges of infrastructure delivery in the rural communities of Ondo North Senatorial District and make appropriate recommendations capable of ensuring sustainable rural infrastructure delivery. The paper focuses on rural water, rural health, rural electricity and rural roads.

\section{Study Area and Method}

The study was conducted in Ondo State. The State was created from the defunct western region on $3^{\text {rd }}$ of February 1976 with administrative capital in Akure. The State is located in the Southern zone of Nigeria. It is bounded on the East by Edo and Delta States, on the West by Ogun and Osun State on the North by Ekiti and Kogi States. The people of the state are predominantly Yoruba, although other Nigerians and Foreign nationals equally live in the state (Official website of Ondo State, 2013).

Field work for the study was carried out in Ose and Akoko North West Local Government areas of Ondo North Senatorial district in Ondo State, predominantly occupied by the Ireakari's, Ekamarun's and Akoko's. the survey took place in four communities, namely ljagba/Imoru, Elegbeka, Ikaram and Irun Akoko. Both primary and secondary method were adopted to source the needed data. The primary data was carefully generated through face to face interview, while secondary data was elicited via relevant texts, journals, magazines, newspapers, reports, conference papers and the internet. The study adopted descriptive and interpretative methods for the analysis of data. 
INTERNATIONAL JOURNAL OF ACADEMIC RESEARCH IN BUSINESS AND SOCIAL SCIENCES Vol. 11, No. 2, 2021, E-ISSN: 2222-6990 @ 2021 HRMARS

Figure 1: Map Showing Ondo State and Its Local Government Areas
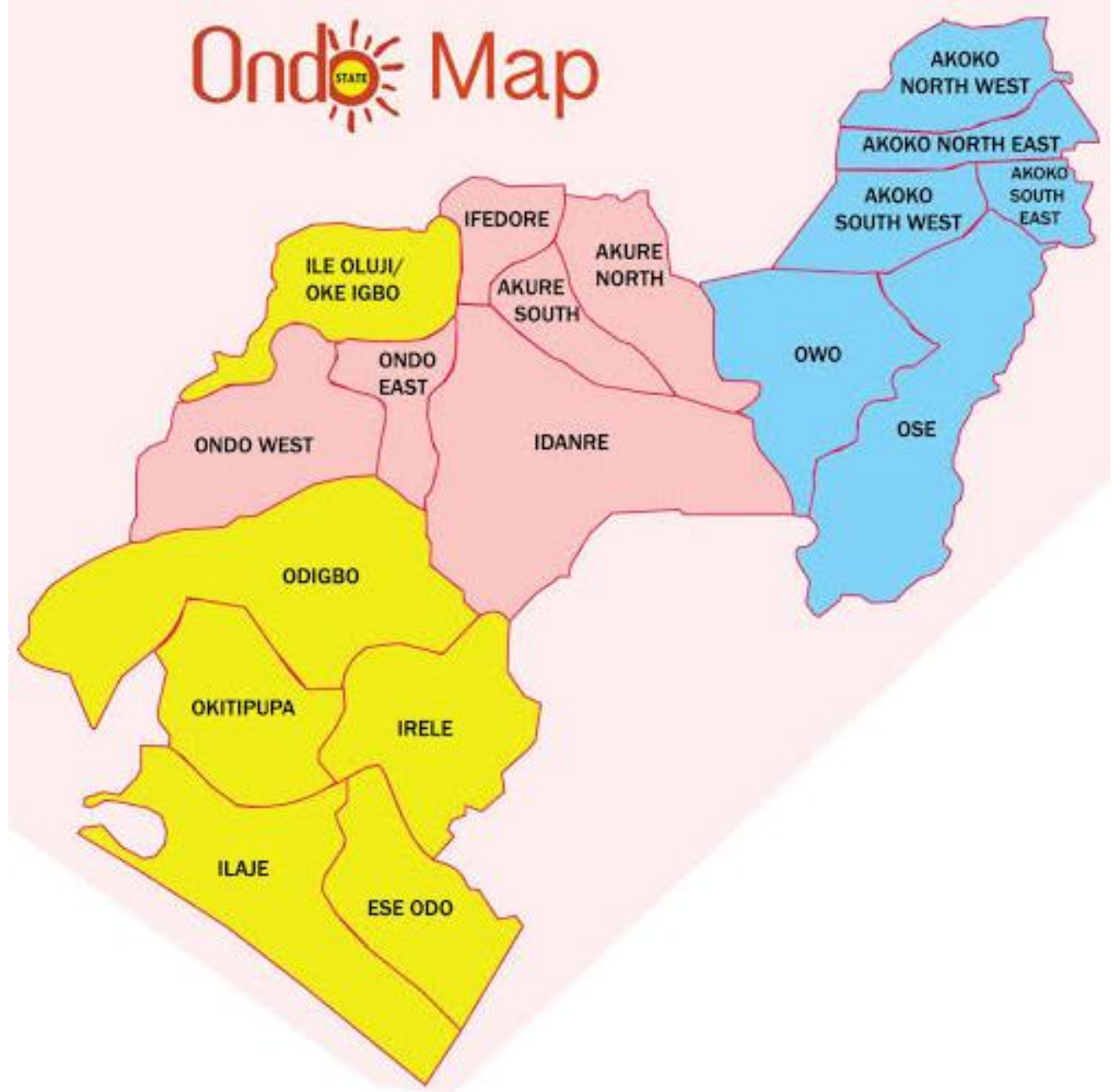

Source: Premiumtimesng.com 


\section{Theoretical Analysis}

Since infrastructure is a global issue, it is imperative to trace its history as it will serve as a foundational pillar to its definition. Historically, infrastructure is related with the origin of human civilization. According to Adesoji and Chike (2013), the word infrastructure has been used in English since at least 1927, originally measuring "the installations that form the basis for any operation or system". Oxford English Dictionary trace the word's origin to earlier usage, originally applied in a military sense. The word was imported from French, where it means subgrade, the nature materials underneath a constructed pavement or railway. The word is a combination of the Latin prefix "infra" meaning "below" and "structure". The military use of the term achieved currency in the United States after formation of NATO in the 1940s, and was then adopted by urban planners in its modern civilian sense by 1970 . The term came to prominence in the United States in the 1980s following the publication of "America in Runs", which initiated a public-policy discussion of the nation's infrastructure crisis, purported to be caused by decades of inadequate investment and poor maintenance of public workers. Attention and discussion on this crisis have contributed to the increase in infrastructure asset management and maintenance planning in the United States (Adesoji \& Chike, 2013).

While some economists associate infrastructure with economic and social overhead capital, which includes facilities such as power, transport and communications, other social scientists see it as embracing social overhead which includes facilities for water supplies, education, health, information, town and country planning and social welfare. Ubi et al., (2011) has clarified that the definition of infrastructure falls into two complimentary categories, namely; social or soft - core infrastructure and physical for hard - core infrastructure. In their empirical analysis, soft-core infrastructure pertains to the provision of healthcare and education, governance while hard-core infrastructure pertains to physical structures and comprise telecommunication, power, transportation, water supply and sewage. They are generally viewed as wheels of economic activity. Drawing from the foregoing, infrastructure, be soft core or otherwise, provide the basic foundation on which the take-off into self-sustaining development is not only possible but is also assured.

Scholars have come up with different models and approaches of infrastructural development in rural communities. Wanmali et al., (1997) argue that the pattern of rural infrastructural provision can be understood by employing the centre-periphery model of rural settlements. According to them the centre-periphery model is one of many variations on a theme that impose a structural concept of centre and periphery on what might be considered respectively developed and backward areas, whether on a sub-national, national or global level. The model can be used to investigate the impact of access to rural service infrastructure and the overall demand for goods and services in the rural communities. In their analysis, the centre-periphery relationship is a relationship where factors of production, raw materials and agricultural goods are drawn from the periphery to the centre, where they are used to produce high value manufactured goods. In time, service infrastructure becomes concentrated in the centre (commonly towns and urban arears). The centre-periphery model is useful in the context of the study to understand the pattern of access and existing gaps between the rural dwellers and infrastructure delivery.

Africa Development Bank (2009) scientifically observed that Africa lags behind other continents in the area of infrastructure. In its studies, ADB reports that the deficiency in infrastructure was particularly greater in the area of water and sanitation (65\% coverage for sub-sahelian countries against a total of $82 \%$ for developing countries as a whole), electricity 
was $24 \%$ against $58 \%$ ) and rural road access was $34 \%$ against $90 \%$. According to ADB, Africa will require yearly investment of US $\$ 22$ billion in infrastructure on the continent. In line with the foregoing, a survey carried out by the World Bank (2009) found that the Africa's infrastructure in terms of quality and quantity is grossly inadequate and inferior to that existing in other parts of the world. It is to be noted that among the continents accessed in the global competitiveness report in 2009, the Africa's quality of infrastructure was ranked the last. This is consistent with the ADB survey results where manufacturing forms listed infrastructure as their most severe business constraint.

According to World Bank (2010), millions of people in developing countries are faced with acute water stress from inadequate supplies. Official World Health Organisation (WHO) figure suggest that between 2009 and 2010, 800million people in urban areas lack access to portable water close to their homes. Evidence from rural communities reveals that more than 1.2 billion people are still without safe water (World Bank, 2010). Hall (2013) further revealed insufficient or lack of provision of pipe borne or portable drinking water where $50 \%$ of the city dwellers and $90 \%$ of rural dwellers lack access. As a result, large proportion of households have resorted to drawing water from unhygienic sources in the rural societies of Africa.

Lokesha and Mashesha (2017) have argued that people in rural areas directly or indirectly depends on agriculture for survival and agricultural activities require good road network to stimulate socio-economic development because road transport provides the basic transport infrastructure in rural areas for bringing farm produce and other agricultural products to market. According to them, rural roads promote access to economic and social services. It leads to efficient delivery of farm inputs.

Manggat, et al., (2018) describe the distribution of infrastructure between the rural and urban areas as a necessity. They explain that the rapid growth in the rural economics is determined by the accessibility and the delivery of essential infrastructures. They posited that rural development planning should be considered as part of national and overall development which needs to include the economic growth, the increase in health services, access to education and the community development itself. Adeniyi, Akinrinmade and Abiodun (2018) said roads in rural areas of Nigeria are often ignored and neglected by the government because rural areas are remote and often voiceless. The inability of local government in Nigeria to play significant and meaningful role in the development of rural communities contributes to rural infrastructural deficit and the continuing gaps in rural development. Lawal (2014) in similar vein opined that lack of democratic governance at the grassroots was responsible for rural infrastructural deficit. He argued that the appointment of officials by state governors to represent the people cannot facilitate good governance. He noted that imposition of representatives had also led to imposition of infrastructures. He therefore advocated true and participatory democracy at the local government level for sustainable rural infrastructure delivery.

\section{The State of Rural Infrastructure in Nigeria}

Sulaiman (2012) observed that with the relatively massive financial resources pumped into the Nigerian economy since the ascendancy of the oil industry in the 1970s, infrastructure facilities have been reasonably provided, but only a contemptible few of them go to the rural areas where a reasonable number of people live. According to him, there have been continued growing of urban bias in resource allocation and location of social services and development projects. 
Alabi and Ocholi (2010) have described the state of infrastructure in Nigeria as poor and grossly inadequate. In their article titled "the state of infrastructure in Kogi State Nigeria found that the Nigeria's infrastructure in term of quality and quantity is grossly inferior to that existing in other parts of the world. Alabi and Ocholi further observed that in most rural areas of Nigeria there are insufficient or lack of provision of pipe borne or portable drinking water, where more than $85 \%$ of the rural dwellers lack access, as a result, $10 \%$ of households have their own private deep wells and very many rely on water vendors whose high prices amount to more than $30 \%$ of the household income for the poorest, as a result, large proportion of households have resorted to drawing water from unhygienic sources. They also observed the prevalence of poor road network. According to them, Nigeria roads have been found to be the lowest in density in Africa, where only $31 \%$ of the roads are paved as compared to $50 \%$ in the middle-income countries, and even where roads are provided only 40 percent of these roads can be said to be in good condition. Their findings also revealed that electricity supply in Nigeria, and particularly in rural areas is deficient. According to them, only 10 percent of rural households have access to electricity.

Adewole (2019) has described state of health infrastructures in rural communities in Nigeria as inadequate. The report noted that the quality of health service delivery was low particularly in the rural areas of Oyo and Osun States where the research was conducted. He observed that most of the health centres and maternity homes lacked necessary equipment and drugs that could bring about improvement in health service delivery.

According to him, the risk for maternal death in rural areas is 100 times higher than in urban areas and risk for pregnancy-related illness and negative consequences after birth is higher.

Health centres in rural communities have been noted for lack of basic drugs and required personnel, which invariably affect negatively the operation of the centres (Ajetomobi, 2019). In the work of Ajayi (2019) titled" The role of Community Health Workers in Rural Health Service Delivery" it was revealed that most rural communities do not have functional health centres nor maternity. Ajayi maintained that there is death of health infrastructures in rural communities of Nigeria. In his report, out of 120 communities surveyed in Nigeria, only 20 communities have functioning health centres, while 12 have maternity homes. He described the situation as "death trap" for the rural communities as most rural residents tends to rely on herbs, and traditional birth attendants for the pregnant women.

It is evident from the foregoing that rural infrastructure delivery in Nigeria is still deficient as most rural communities have continued to lack basic amenities needed to achieve qualitative life.

\section{Rural Infrastructure Delivery in Ondo North Senatorial District}

The two local governments and the four communities surveyed in Ondo North Senatorial District are basically rural communities dominated by farmers and traders, where functional infrastructures are expected based on their economic and political roles to the development of the Ondo State in particular and Nigeria in general. Bulk of the agricultural products consumed in the cities are brought from these communities and reasonable number of votes are also generated from same communities. It is therefore unarguably expected that the residents of these communities should feel the presence of government via functional infrastructures. However, most of the communities visited are severely challenged by nonfunctional infrastructures. Although, some of these infrastructures like water, electricity 
roads and health centres are provided but larger numbers are not functional. According to a respondent in Elegbeka Community:

Government always come here to deceive us when they need our votes, all the boreholes constructed are not working. We fetch water from streams and well and those that have means go to Ifon, a nearby town to get drinking water. The health centre we have does not have doctors, but only the nurses. No pharmacy at the health centre and even in the whole community. We travel to Owo or Ifon to purchase the prescribed drugs. The worst of it is electricity, we have not had electricity in the last two years.

The foregoing was corroborated by a respondent from Ikaram Akoko when said; we only see them during election, they come here to do a face dressing for our roads and disappear until the next election. Our community has five (5) quarters, namely Oyagi, lyoke, lyotu, Ayeteju, Itabalogun. It is only Itabalogun that has good water supply. "Kamumi Aketi" a government water project that is on-going in the community that would have solved the water problem in the whole village would have been completed but was abandoned due to Covid-19 and has not been revisited since then.

Another respondent, a farmer and trader complained about the state of electricity, roads and health facilities. According to him, most of these infrastructures are just there without much impact. In his words;

Electricity is available but most houses are not metered, estimated billing is operational here, which makes it unaffordable for most of us in the community. Our health centre is there with inadequate personnel, inadequate drugs, no pharmacy in the health centre, we go to Ikare a neighbouring town for drugs. Most roads leading to our farms are in bad shape. It is difficult to move farm products in the raining season because of bad roads. 
It is also to be noted that most of the infrastructures visited by the researchers are in state of disrepair, some are partially working while some have been abandoned for many years. Below are some of the infrastructures.

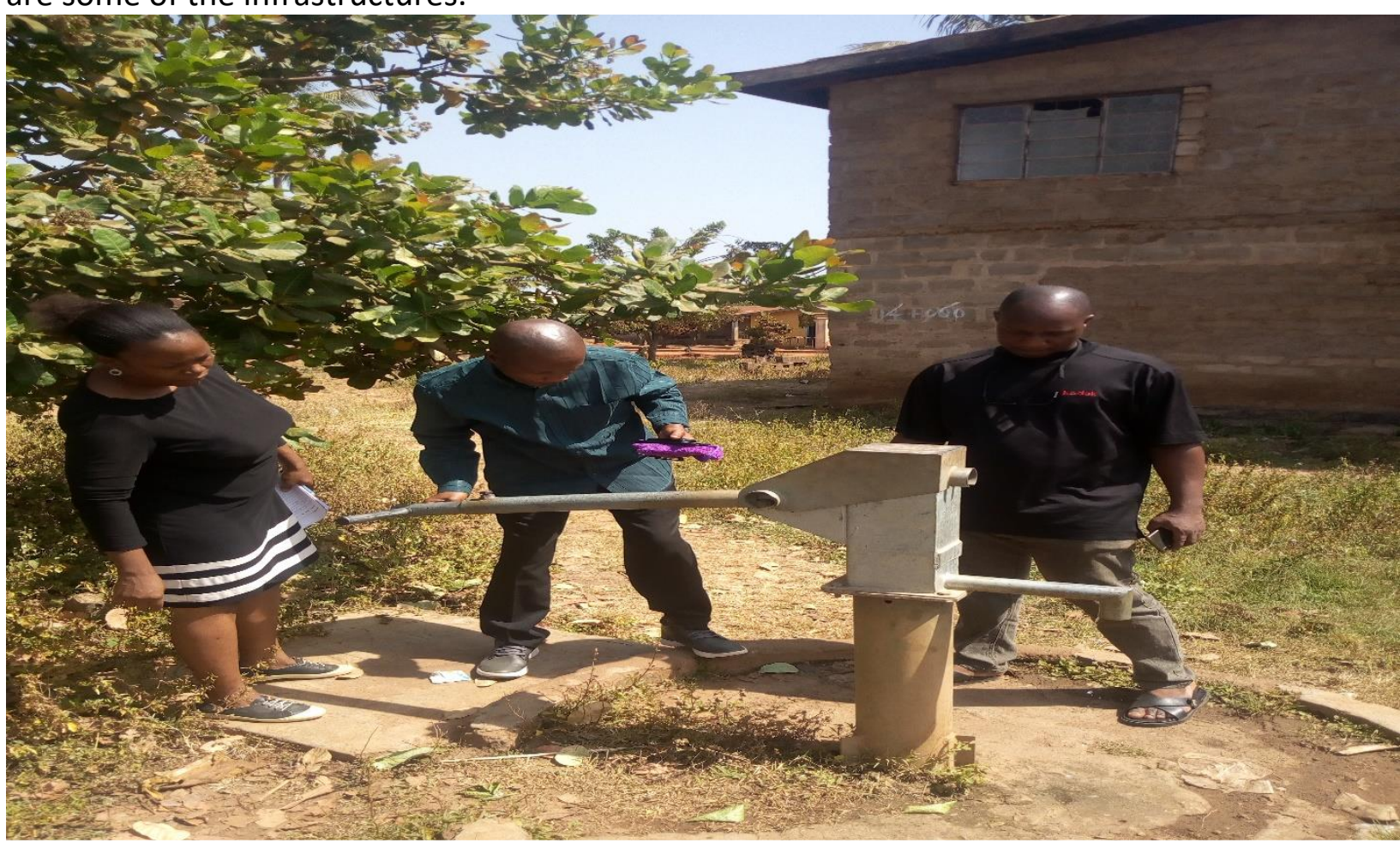

Fig. 1: Researchers assessing rural water project in Ikaram Community

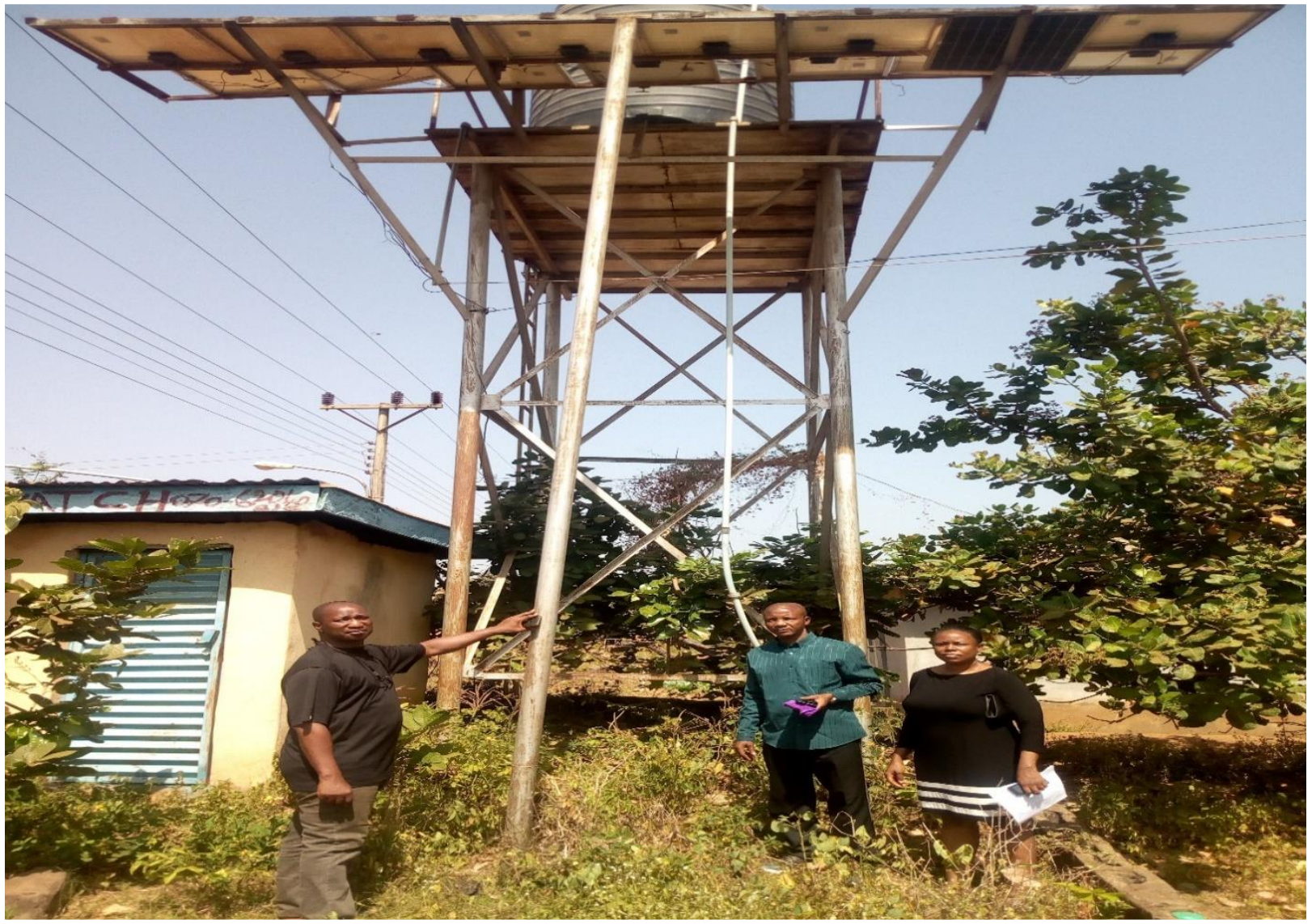

Fig. 2: Pictorial view of rural water project in Ijagba/Imoru Community 


\section{My brothers and sister, please tell government to give us portable water and regular supply of electricity. We pay our taxes regularly let government also provide us basic amenities.}

In the same vein, a chief, and farmer was of the opinion that;

Our community has been long neglected

by the government. We have not seen light for more than two years in our community. Accessible roads cannot be found anywhere. Vehicle cannot enter our farm because of the bad roads. We use 'okada' (motorcycle) and bicycle to transport farm products. We are really suffering we need government attention.

From the analysis, it is obvious that government is only paying little attention to the rural infrastructure maintenance. Infrastructure provision without maintenance is not delivered, as such infrastructure will not deliver the expected benefits to the people, as such it will have little or no impact on the communities.

\section{Crisis and Vices of Sustainable Rural Infrastructural Delivery}

The findings from in-depth interview show that rural infrastructure delivery is faced with various challenges. One of these challenges is poor maintenance culture, the study found that most of the infrastructures provided for the sampled communities were not functioning as a result of poor maintenance. Some of the infrastructures have become old and need repair and replacement. It is crystal that when infrastructures are not regularly maintained, the issue of sustainability becomes almost impossible.

Another challenge that is directly linked to poor maintenance is the lack of continuity of government policies and programmes. The findings showed that most infrastructural projects that serve same purpose were repeatedly provided by different administration or regimes.

Affordability is another challenge. A respondent in Ikaram vehemently said that many cannot pay for estimated billing for electricity due to low income earnings. Another crisis that engulfs rural infrastructure delivery is imposition of projects on the communities. Non-involvement of the residents in the planning and execution of projects constitute a serious challenge to rural infrastructure delivery. For effective rural infrastructure delivery, local actors are expected to participate in the decision about the strategy and in the selection of priorities to be pursued in their local area.

It is also observed that corruption poses a serious setback to rural infrastructure delivery. Many projects were abandoned having diverted funds meant for them into private use by government officials. Yagboyaju and Akinola (2019) have argued that the country's abundant resources are yet to be harnessed to combat the impoverishment of ordinary Nigerians. This is due to the corrupt nature of leadership in Nigeria, particularly at the grassroots.

Communal conflict can also affect development in the rural areas. Where conflict and violence between two or more communities and among various groups is prevalent, there is possibility of development crisis (Olaniyan, 2020b). Most of the rural areas are laced with group and 
community conflict, thereby making it difficult for them to jointly participate in development programmes.

Another interesting challenge to rural infrastructure delivery is the initiation of projects for political and electoral reasons. The respondent reported that some projects were flagged off to garner support during campaigns, but such projects never saw the light of the day as most were abandoned after the election. Also, most of the projects were quick win projects designed to buy vote from the rural residents during elections (Olaniyan, 2020a).

In addition, insecurity in the recent years, particularly in the ungoverned spaces has contributed to the problem of rural development. There have been security threats arising from kidnapping in the rural areas, which has made it difficult for rural dwellers to actively engage in agricultural and other productive activities. Olaniyan (2017) identified forest (ungoverned spaces) as a security threat in Nigeria. It is to be noted that most of these threats are commonly perpetrated in the rural setting, which are capable of endangering development at the grassroots.

\section{Addressing the Rural Infrastructure Gaps}

Based on the result of this study, it becomes fashionable to suggest new models or strategies by which rural infrastructure gaps can be addressed to ensure appropriate, sustainable affordable and qualitative rural infrastructures. The following recommendations are therefore put forth.

One, there should be routine and regular maintenance of rural infrastructures. Repairs and rehabilitation of the existing facilities must be emphasized over and above new ones. Creating new infrastructures on regular basis will be more expensive in the long run if the existing ones are allowed to run down that it must eventually be replaced at great costs. To ensure this, government can set-up committees at ward level, which will include community leaders and other interest groups that will oversee projects within the community and play the role of an early warning such as alerting government on certain infrastructures getting into disrepair and also helping to develop maintenance system. These committees should meet on regular and periodic basis to review and evaluate the performance of various infrastructures and report same to government for onward action. Such committees must be pro-active and the members must be selected based on the following criteria; retired public servants that are trusted with high sense of integrity; those who are resident in the affected communities; those who have contributed positively to the development of the communities; traditional rulers and community leaders; possession of quality of hard work, transparency and accountability; sense of commitment, integrity, honest and patriotism. Two, government must ensure occasional visit to these communities to ascertain the status and condition of these projects, assess and evaluate the quality of work done by the contractors. This will reduce or eliminate the habitual use of substandard materials by the contractors, and subsequently enhances project sustainability.

Three, continuity as a policy must be promoted in governance process. Since government is adjudged as a continuous process, policies, programmes and projects of government should also be seen as continuous process. The idea of mounting new projects by new government over the existing same projects need to be discouraged and discarded so as to reduce or eliminate abandonment of projects. Most projects were abandoned for no tangible reason, some abandonment was even politically motivated. This negative attitude should be discouraged in governance to allow effective and sustainable rural infrastructure delivery. 
Four, government should jettison the idea of imposing projects on rural communities. Communities differ in nature and degree of their needs. Every community may not need the same thing. It is therefore necessary for the government to be sensitive to different ecological situations and seek to develop the communities along a direction the rural people can well appreciate. It is important for government to ask questions such as; what are the people's priority needs? What infrastructure projects will best address those needs? Rather than to impose project on them. The rural people should be genuinely involved in the planning, execution and maintenance of rural projects as this will encourage claim of ownership by the residents and subsequently encourage them to maintain and protect the projects.

Five, government should ensure that some of these infrastructures are made affordable for the rural residents. For instance, electricity supply and health service delivery. Drugs should be made available and affordable at the rural health centres. In the same vein, government should ensure that pre-paid meters are made available to rural residents at a controlled price to avoid arbitrary and high charges on regular basis by the officials of electricity distribution companies.

Six, is genuine fight against corruption. Corruption has been identified to be responsible for infrastructural gaps in rural communities of Ondo State. There is urgent need to genuinely punish corruption at all governmental levels. Anybody caught in the act should be made to face the music as this will serve as deterrence to others. The two institutions created for this purpose i.e. Economic and Financial crimes Commission (EFCC) and Independent Corrupt Practices and other related offences commission (ICPC) to fight corruption should be made effective and truly independent so as to genuinely perform their duties. Most cases handled by these institutions have remained inconclusive, even when there were evidences of corruption practices. Security in the rural areas must be beefed up to ensure safety of lives and properties.

\section{References}

Adeniyi, T. O., Akinrinmade, Y., \& Abiodun, A. L. (2018). Analysis of Road Transport Impact on Rural Development in Nigeria: A Study on Akure North Local Government Area, Ondo State. International Journal of New Technology and Research, 4 (3), 102-110

Adewole, S. O. (2019). Health Care Delivery System in Nigeria: Rural Health Delivery Option. Lagos: Malthouse Printing Limited.

African Development Bank (2009). Infrastructure Development in Africa. Africa Development Report, Oxford University press.

Ajayi, S. O. (2019). The Role of Community Health Workers in Rural Health Service delivery. Nigeria Journal of Social Sciences, 2(3) 42-55.

Ajetomobi, A. A. (2019). Impact of Health Services on Rural development: Nigeria in focus. Lagos: Oniwuku publisher.

Alabi, M. O., \& Ocholi, I. (2010). State of Infrastructure and funding in Kogi State, Nigeria. Current Research Journal of Social Sciences, 2 (3), 209-213.

Gnade, H. (2013). The Effect of Basic Infrastructure Delivery on Welfare in Rural and Urban Municipality. Retrieved from

https://www.edu.org.29/took/box/docs/government/infrastructure.html. Accessed on $10^{\text {th }}$ May, 2014.

Hall, D. (2013). Sustainable Infrastructural Development: A workable Approach. Journal of Economics and sustainable Development, 5(8), 35-47. 
Lawal, T., \& Imoukhuede, B.K (2018). Local Government Finance and Rural Infrastructure Delivery in Ondo State: A Study of Ondo West Local Government Area, 2010-2015. African Journal of Institutions and Development xiii (23 \& 24) 110-121.

Lawal, T. (2014). Local Government and Rural Infrastructural Delivery in Nigeria. International Journal of Academic Research in Business and Social Sciences, 4(4), 139-147.

Lokesha, M. N., \& Mahesha, M. (2017). Economic Benefits of Road Infrastructure on Agricultural Development and Rural Road Infrastructure Development Programmes of India and Karnataka. Journal of Research in Business and Management 4(11), 42-48.

Manggat, I., Zain, R., \& Jamahiddin, Z. (2018). The Impact of Infrastructure Development on Rural Communities: A Literature Review. International Journal of Academic Research in Business and Social Sciences, 8 (1), 637-648.

Official website of Ondo State, 2013

Olaniyan, A. (2020a). Election Sophistication and the Changing Contours of Vote Buying in Nigeria's 2019 General Elections. The Round Table. 109 (4), https://doi.org/10.1080/00358533.2020.1788762.

Olaniyan, A. (2020b). A Bad Child Has His Own Day: Gwama Boys and Post-conflict Peacebuilding Dilemma in Oil-bearing Communities of Ondo State, Nigeria. African Identities. https://doi.org/10.1080/14725843.2020.1813547.

Olaniyan, A. (2017). Foliage and Violence: Interrogating Forests as a Security Threat in Nigeria. African Security Review. https://doi.org/10.1080/102246029.2017.1369135.

Ogbuagu, U., Ubi, P., \& Effiom L. (2014). Corruption and Infrastructural Decay: Perceptile Evidence from Nigeria. Journal of Economic and Sustainable Development, 5(10), 20 27.

Sulaiman, K. (2012). Rural Development Administration in Nigeria. In S.I. llufoye, \& J. Amsat (Eds.) The Basic of Social Sciences (pp. 537-556) Lagos: Malthouse Press Ltd.

Uhunmwuangho, S. O., \& Ekpu, C. (2012). Analysis of Socio-Political Implication of Infrastructural Decay in Nigeria. African Research Review, 6(40), 40-58.

Wanmali, S., \& Islam, Y. (1997). Rural Infrastructure and Regional Development in Southern Africa, In L.H (Ed). Achieving Food Security in Southern Africa: New Challenges, New Opportunities (pp. 10-25). Washington, DC: IFPRI.

World Bank. (2009). Road Deterioration in Developing Countries: Causes and Remedies. Washington DC: The World Bank.

World Bank. (2010). Development Report. The Importance of Infrastructure to Economic Development. An Example from China. Washington DC: The World Bank.

World Bank. (2014). Rural Roads and Rural Development: The Interface. Washington DC: The World Bank.

Yagboyaju, D. A., \& Akinola, A. O. (2019). Nigerian State and the Crisis of Governance: A Critical Exposition. Sage.

https://journals.sagepub.com/doi/pdf/10.1177/2158244019865. 